\title{
A genome-wide scan of non-syndromic cleft palate only (CPO) in Finnish multiplex families
}

\author{
H Koillinen, P Lahermo, J Rautio, J Hukki, M Peyrard-Janvid, J Kere
}

J Med Genet 2005;42:177-184. doi: 10.1136/jmg.2004.019646

O ral clefts are the most common congenital malformations worldwide. Cleft palate can be non-syndromic (MIM 119540) or it can appear as a part of a syndrome or recurrence pattern. Non-syndromic cleft palate and non-syndromic cleft lip with or without cleft palate $(\mathrm{CL} / \mathrm{P})$ are considered to be separate entities, on the basis of different embryonic timing and epidemiology. However, in some syndromes, both of these cleft types segregate in the same pedigree, suggesting that they might share a common genetic background. Oral clefts manifest in over 300 different syndromes, and in some of these syndromes the gene defect is already known (Online Mendelian Inheritance in Man database 2004, http://www.ncbi.nlm.nih.gov/Omim/). Identified mutations in cleft syndromes have shown that functionally and structurally very distinct types of genes have an effect on palatogenesis. Recently, a mutation in interferon regulatory factor 6 (IFR6) was found to cause van der Woude syndrome (VWS) (MIM 119300), ${ }^{1}$ which is one of the most common cleft syndromes.

Mutations in very different type of genes can lead to cleft palate in mice. These genes encode growth factors, receptors, transcription regulators, and enzymes for signalling molecule synthesis. Cleft palate, in addition to other congenital malformations, is found in $\sim 70$ knock out mice strains (The Transgenic/Targeted Mutation Database, http://tbase. jax.org/). Other anomalies occur frequently, and therefore no exact model for non-syndromic cleft palate exists. Usually the penetrance is not complete, but Msx-1 knock outs result in $100 \%$ cleft palate. ${ }^{2}$

It has been suggested that, in humans, $\sim 50 \%$ of cases of cleft palate are non-syndromic. ${ }^{3}$ The etiology and pathogenesis of non-syndromic cleft palate-and also of all other clefts-are poorly understood. Extrinsic factors, such as maternal smoking ${ }^{4}$ with a particular allele in TGF $\alpha$ locus, ${ }^{5-7}$ maternal alcohol consumption, ${ }^{89}$ maternal intake of drugs during the first trimester, ${ }^{10}$ and advanced paternal age, ${ }^{10}$ have been shown to increase the risk of cleft palate only (CPO) in some studies, but conflicting results have also been published. Sparse intake of folic acid during the first trimester has been suggested to increase the risk for cleft palate. ${ }^{11} 12$ The increased recurrence risk for siblings and the even higher risk for monozygotic twins suggest a genetic impact on cleft formation. ${ }^{313}{ }^{14}$ Some families have shown a dominant mode of inheritance, ${ }^{15}$ but oligogenic models with reduced penetrance and influence of extrinsic factors have also been proposed. ${ }^{16}{ }^{17}$ The risk of recurrence is $\sim 2 \%$ if one child already has a CPO, $\sim 6 \%$ if one parent has it, and $\sim 15 \%$ if one child and one parent have it. ${ }^{18}$ At the moment, nonsyndromic cleft palate is considered to be a multifactorial disease with a strong genetic background combined with extrinsic factors. ${ }^{3}$ 19-21

The incidence of non-syndromic CPO is $1 / 1000$ live births in Finland, and this is one of the highest rates among white people. ${ }^{22}$ High incidences are seen in regions near Oulu and in central Finland. ${ }^{22}$ These regional differences become even more striking when the birthplaces of grandparents of

\section{Key points}

- Non-syndromic cleft palate is one of the most common congenital malformations worldwide.

- We performed a genome-wide scan of nine Finnish multiplex families affected with non-syndromic cleft palate.

- Chromosomal region 1p34 and the entire chromosomes 2 and 4 were screened in an additional 15 families and with a denser marker map.

- No mutations were detected in IRF6 when screening nine affected individuals from separate families.

- We found suggestive linkage in $1 \mathrm{p} 34(z=1.52)$, $2 p 24-p 25(z=2.29)$, and 12q21 $(z=1.80)$.

probands are analysed; the Oulu region is heavily overrepresented..$^{22}$ Usually, the incidence of cleft lip and palate $(\mathrm{CL} / \mathrm{P})$ is higher than the incidence of $\mathrm{CPO},{ }^{23}$ but in Finland the ratio is the opposite. ${ }^{22}$

Several association and linkage studies on CPO have been carried out. An association between TGF $\alpha 2$ and $\mathrm{CPO}$ has been found in three studies. ${ }^{524}$ Later, Lidral et al found no association between $\mathrm{CPO}$ and $\mathrm{TGB} \alpha$, TGF $\beta 2$, TGF $\beta 3$, or MSXI. ${ }^{25}$ An association between the risk of CPO and variation at the TGF $\beta 3$ locus was found in a Danish population. ${ }^{26}$ Evidence of linkage disequilibrium between CPO and MSXI has been suggested. ${ }^{26}$ Recently, Hecht et al found evidence for a CPO locus on chromosome 4 near MSXI. ${ }^{27}$ MSXI is of special interest because a mutation leading to a preterm stop codon was found to cosegregate with $\mathrm{CL} / \mathrm{P}$ in a large pedigree. ${ }^{28}$ Linkage between CPO and VWS region lq32-q41 has been excluded. ${ }^{29}$ Deletions in 4pl6-14 and 4q31-35 were found to be highly significantly associated with cleft palate. ${ }^{30}$ Duplications in bands 3p24-23, 3p26, 3q23-25, 7q22-32, 8q21, 10pl5-11, 14q11-21, 16pl213 , and 22q12-13 were also found to be significantly associated with cleft palate. ${ }^{31}$ Two patients with cytogenetic rearrangements involving the same region of chromosome $2 \mathrm{q} 32$ were reported to have CPO with mild facial dysmorphia and learning disabilities. ${ }^{32}$

A genome-wide scan has not previously been performed in families with CPO, although several genome scans for $\mathrm{CL} / \mathrm{P}$ have been published. ${ }^{33-38}$ Here, we present the results of the first genome-wide scan in Finnish multiplex families with non-syndromic CPO.

\section{METHODS}

Family material

Data were collected from the records of the Cleft Center, Helsinki University Hospital. Patients with cleft palate in

Abbreviations: $\mathrm{CL} / \mathrm{P}$, cleft lip and palate; $\mathrm{CPO}$, cleft palate only; NPL, non-parametric linkage; WWS, van der Woude syndrome 
A

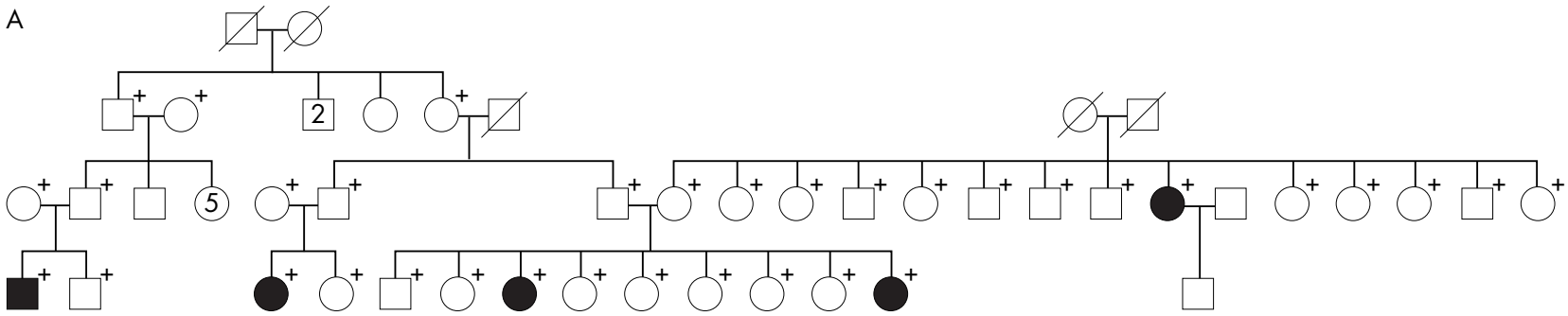

Pedigree 1

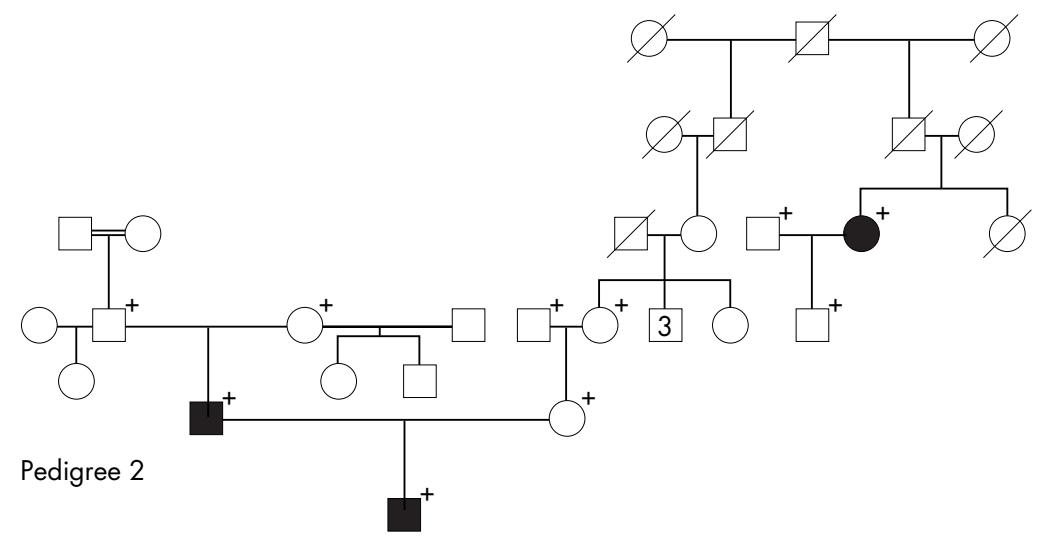

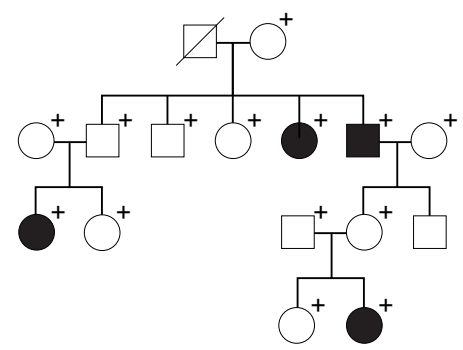

Pedigree 3
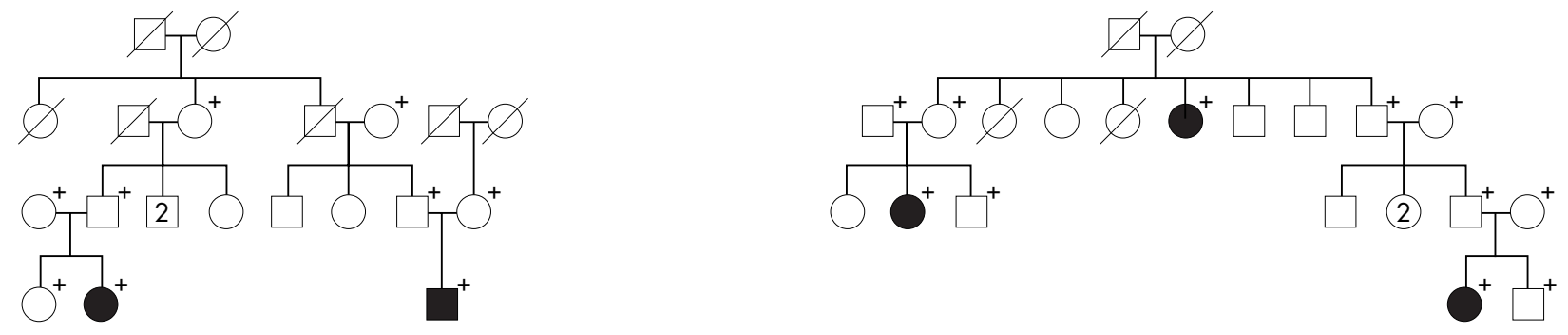

Pedigree 4

Pedigree 5

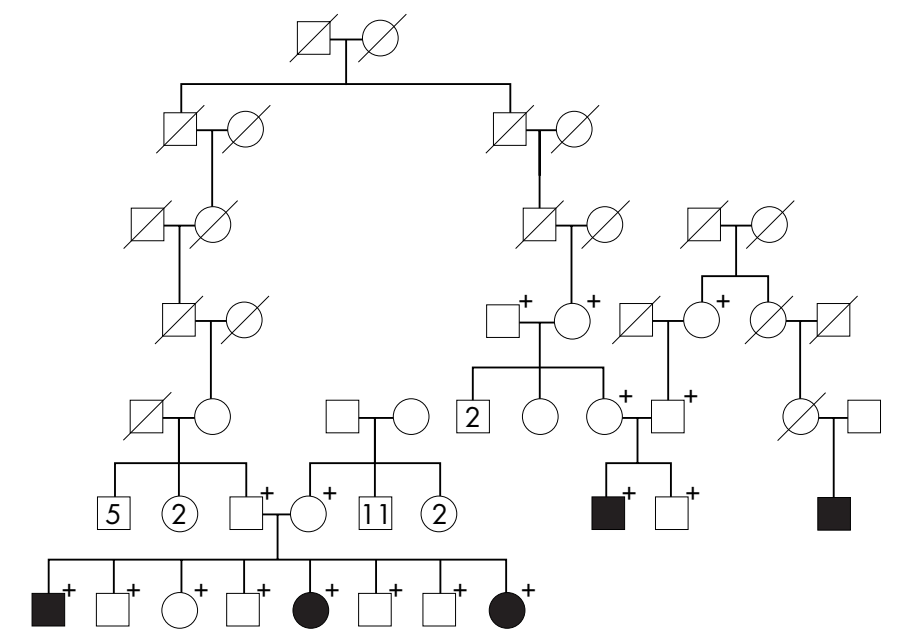

Pedigree 6

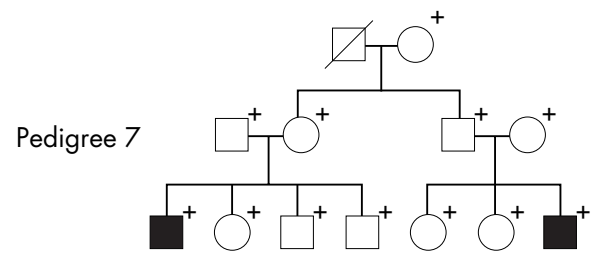

Pedigree 8

Figure 1A Multiplex CPO families, pedigrees 1-8. The genome-wide scan was performed with families 1-9. 1p34 and entire chromosomes 2 and 4 were screened in all 24 families. A cross indicates that a DNA sample was available. 
B $\triangle \varnothing$

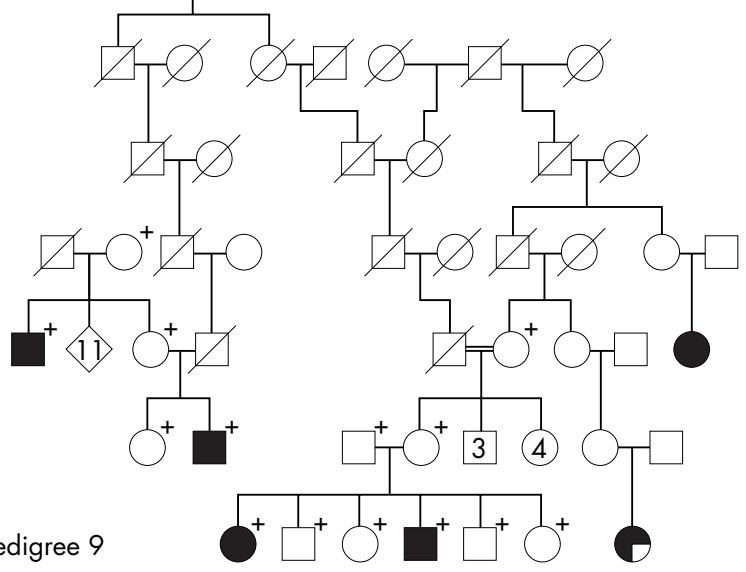

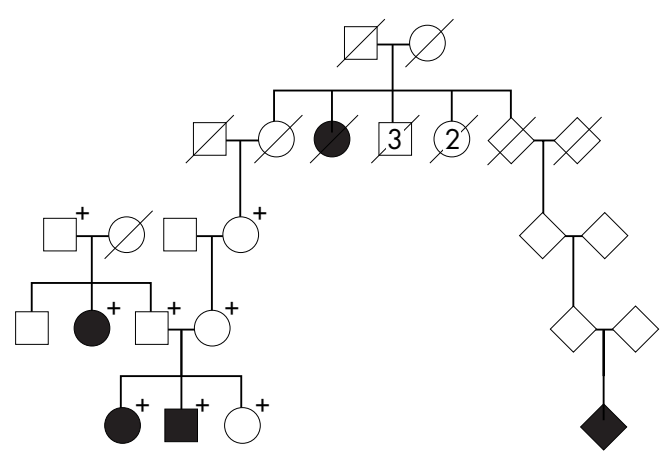

Pedigree 10

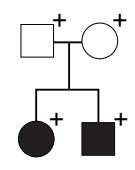

Pedigree 11

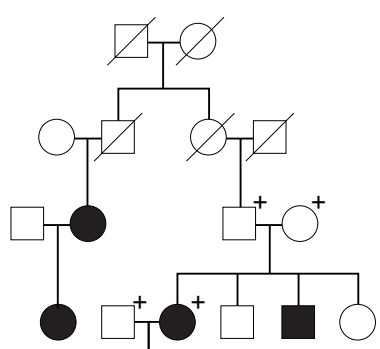

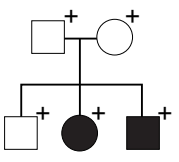

Pedigree 14

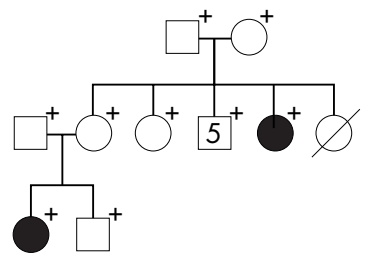

Pedigree 15

Pedigree $12 \mathrm{C}_{+}^{+} \mathrm{\square}^{+}$

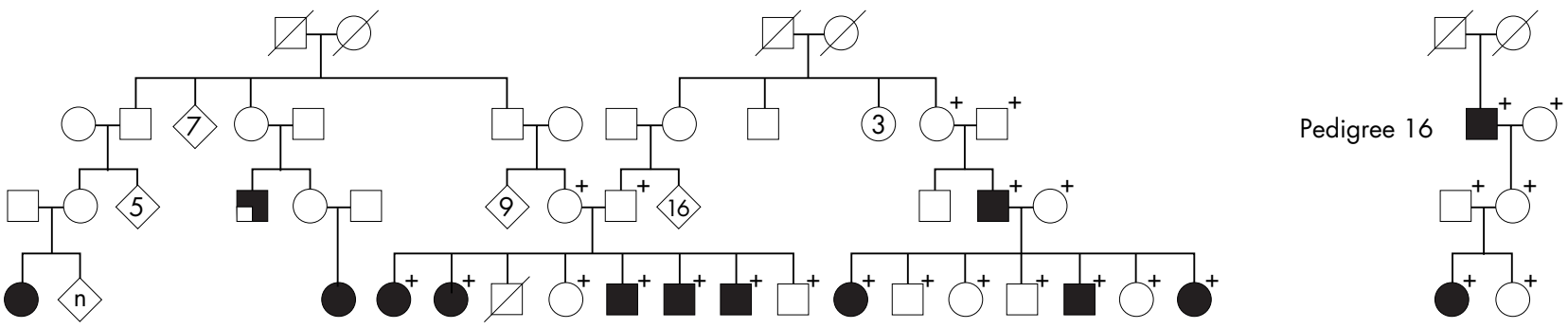

Pedigree 13

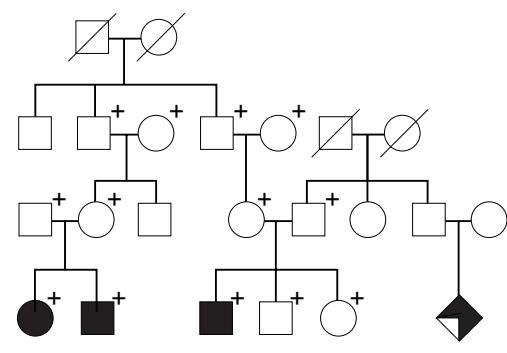

Pedigree 17

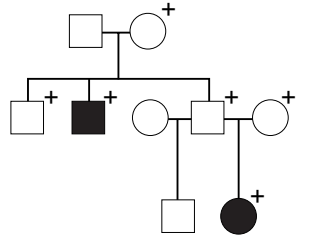

Pedigree 18

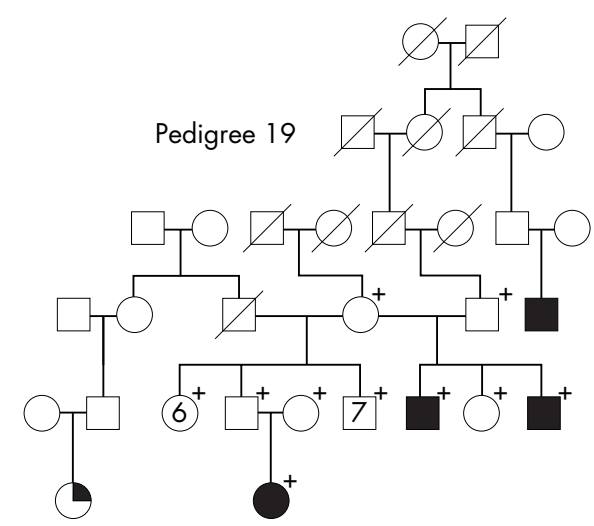

Figure 1B Multiplex CPO families, pedigrees 9-19. The genome-wide scan was performed with families 1-9. 1 p34 and entire chromosomes 2 and 4 were screened in all 24 families. A cross indicates that a DNA sample was available. 
C

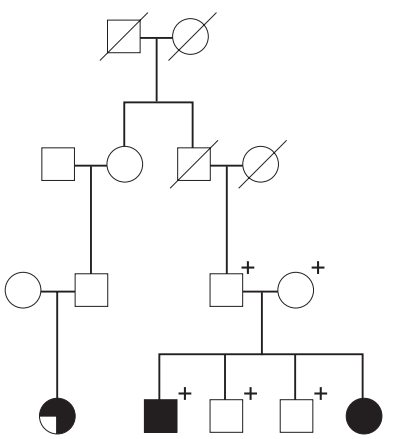

Pedigree 20

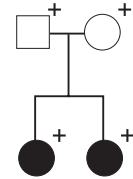

Pedigree 21

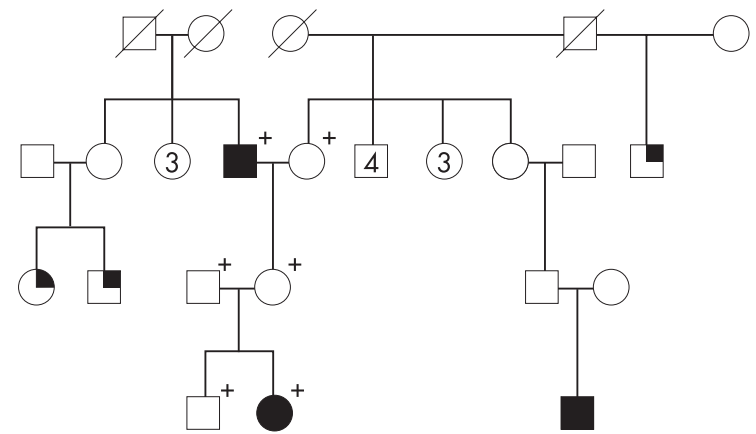

Pedigree 22

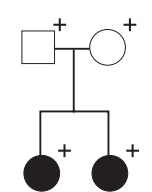

Pedigree 23

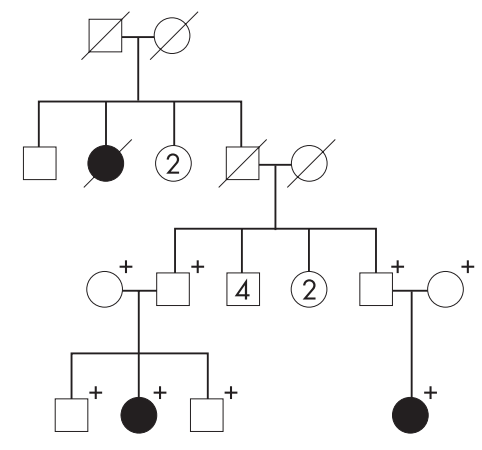

Pedigree 24

Figure 1C Multiplex CPO families, pedigrees 20-24. 1p34 and entire chromosomes 2 and 4 were screened using all 24 families. A cross indicates that a DNA sample was available.

Finland have been treated centrally since 1948 at the Red Cross Hospital for Plastic Surgery, which in 1984 became the Unit of Plastic Surgery of the lst Department of Surgery, Helsinki University Central Hospital. We searched the medical records of all patients with cleft palate from the years 1967-1996 inclusively. We contacted 250 patients by letter. The patients were chosen on the basis of three criteria: (i) according to the medical record they did not seem to have other malformations or any syndrome; (ii) they had reported at least one similarly affected relative; and (iii) they could be contacted by post.

Nine large multiplex CPO pedigrees were chosen for the first stage of the genome scan. The pedigrees consisted of 29 affected and 60 unaffected subjects, making a total of 89 individuals (fig $1 \mathrm{~A}-\mathrm{C}$ ). In addition to these nine families, we scanned the entire chromosomes 2 and 4 and a candidate region in 1 p34 in an additional 15 multiplex families (fig $1 \mathrm{~A}-$ C). In these cases the pedigrees consisted of 63 affected and 112 unaffected subjects, making a total of 175 individuals. The families all came from different regions of Finland. In our study we used the patients' own knowledge about their ancestors and the local church records to build the pedigrees. Ancestors of the patients were traced back three to six generations. Only in one family were the parents of the proband known to be related to each other (pedigree 14). A common ancestor for the probands, previously not known to be related to each other, was found in two pedigrees (pedigrees 7 and 9).

Probands and as many affected relatives as possible were examined by HK to rule out undiagnosed syndromes. The entire nuclear family was asked to meet the examiner if possible. Family members were then examined and any dysmorphic features noted. A blood sample was taken from all available first degree and also some second degree relatives. The ethical committees of the Social and Health Ministry of Finland, the University Hospital of Helsinki, and the Department of Medical Genetics of Helsinki University approved the study protocols.

In our previous study we excluded linkage between CPO and candidate regions/genes (MSX1, TGF $33,2 \mathrm{q} 32$, and 22q11) using these same 24 Finnish multiplex families. ${ }^{39}$

\section{Genotyping and linkage analysis}

DNA was extracted from EDTA preserved blood nonenzymatically. ${ }^{40}$ Genotyping was performed in the Finnish Genome Center (http://www.genome.helsinki.fi) and in the Department of Medical Genetics of the Haartman Institute. In the initial scan with the nine multiplex pedigrees (pedigrees 1-9), 442 polymorphic markers from the ABI linkage mapping set were used. Chromosomes 2 and 4 were screened more densely (using 60 and 51 markers in total, respectively) than other chromosomes because they were of special interest on the basis of literature reports; the average distance is $\sim 10 \mathrm{cM}$ except in chromosomes 2 and 4 where it is $\sim 5 \mathrm{cM}$. In addition, six additional markers (D1S247, D1S513, D1S2723, D1S380, DIS1188, D1S2722) within the region flanked by markers D1S234 and D1S2797 in 1p34 were genotyped. The positions of these markers were ascertained from the Marshfield Comprehensive Human Genetic Map (http://research.marshfieldclinic.org/genetics/ Map_Markers/maps/indexmap.html). At the second stage, we analysed region 1 p34 in an additional 15 pedigrees. Altogether 24 pedigrees were analysed. 
PCR assays were performed in $5 \mu \mathrm{l}$ reaction volumes containing $20 \mathrm{ng}$ of DNA, $1.7 \mathrm{pmol}$ of each primer, $0.25 \mathrm{mM}$ of dNTP, $1 \times$ AmpliTaq Gold Buffer, $0.25 \mathrm{mM}$ $\mathrm{MgCl}_{2}$, and $0.2 \mathrm{U}$ AmpliTaq Gold polymerase (Applied Biosystems; www.appliedbiosystems.com). DNA amplification was carried out as follows: $1 \times 95^{\circ} \mathrm{C}$ for $12 \mathrm{~min}, 10 \times\left(94^{\circ} \mathrm{C}\right.$ for $30 \mathrm{~s}, 55^{\circ} \mathrm{C}$ for $30 \mathrm{~s}, 72^{\circ} \mathrm{C}$ for $\left.30 \mathrm{~s}\right), 20 \times\left(89^{\circ} \mathrm{C}\right.$ for $30 \mathrm{~s}, 55^{\circ} \mathrm{C}$ for $30 \mathrm{~s}, 72^{\circ} \mathrm{C}$ for $30 \mathrm{~s}$ ), and finally $1 \times 72^{\circ} \mathrm{C}$ for $10 \mathrm{~min}$. The alleles were separated electrophoretically on MegaBACE 1000 (Molecular Dynamics) 96 well capillary instruments according to the manufacturer's instructions. The results were analysed and alleles called using Genetic Profiler software from Molecular Dynamics.

The two largest pedigrees (pedigrees 1 and 9) were divided into two for multipoint linkage analysis performed with the Genehunter program. ${ }^{41}$ The data were Mendel checked with
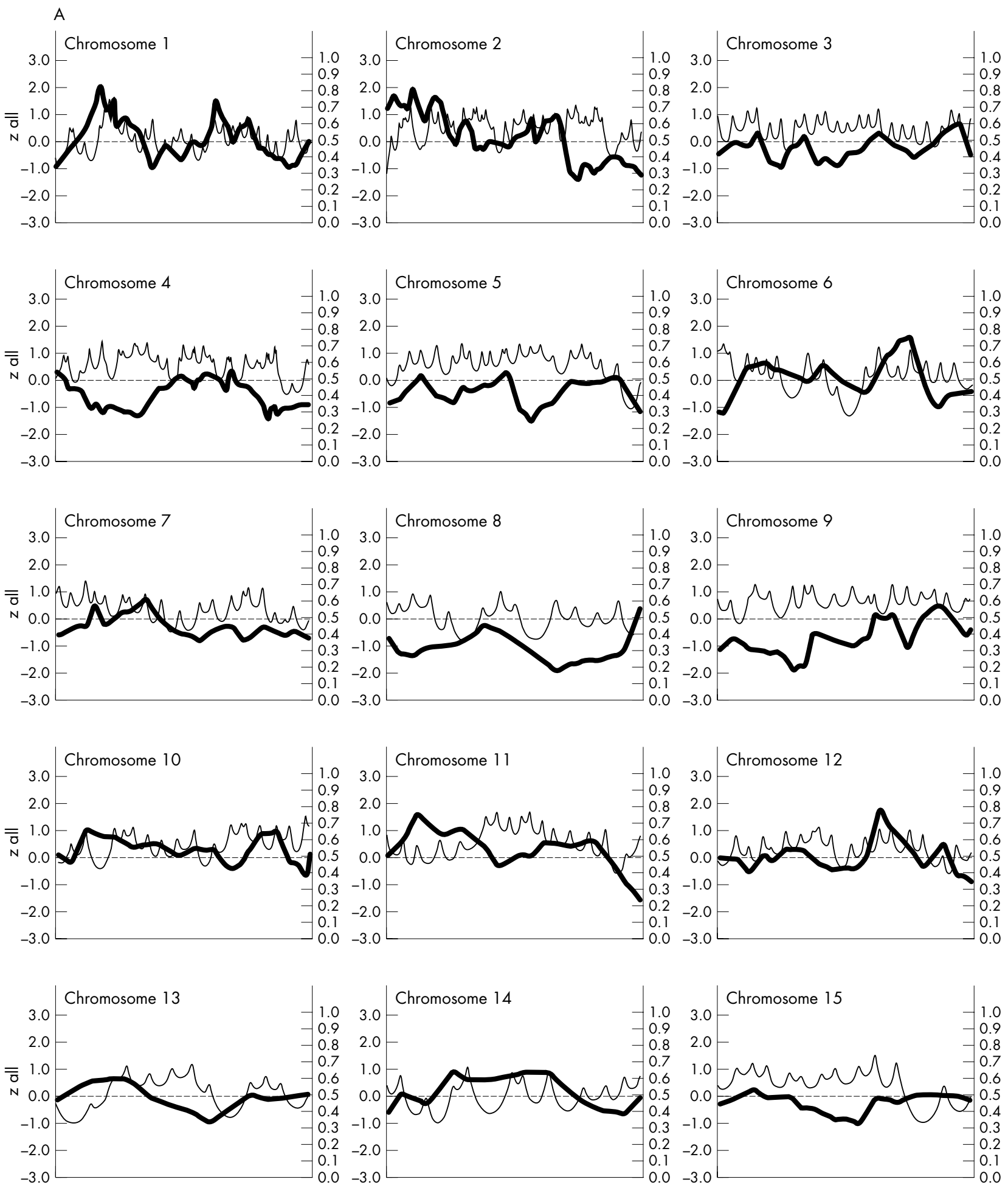

Figure 2A Results of multipoint NPL analysis at stage 1 (pedigrees 1-9, chromosomes 1-15). Thicker curves show NPL scores and thinner curves show information content values. Dotted lines are the zero levels for both NPL and information content values. 

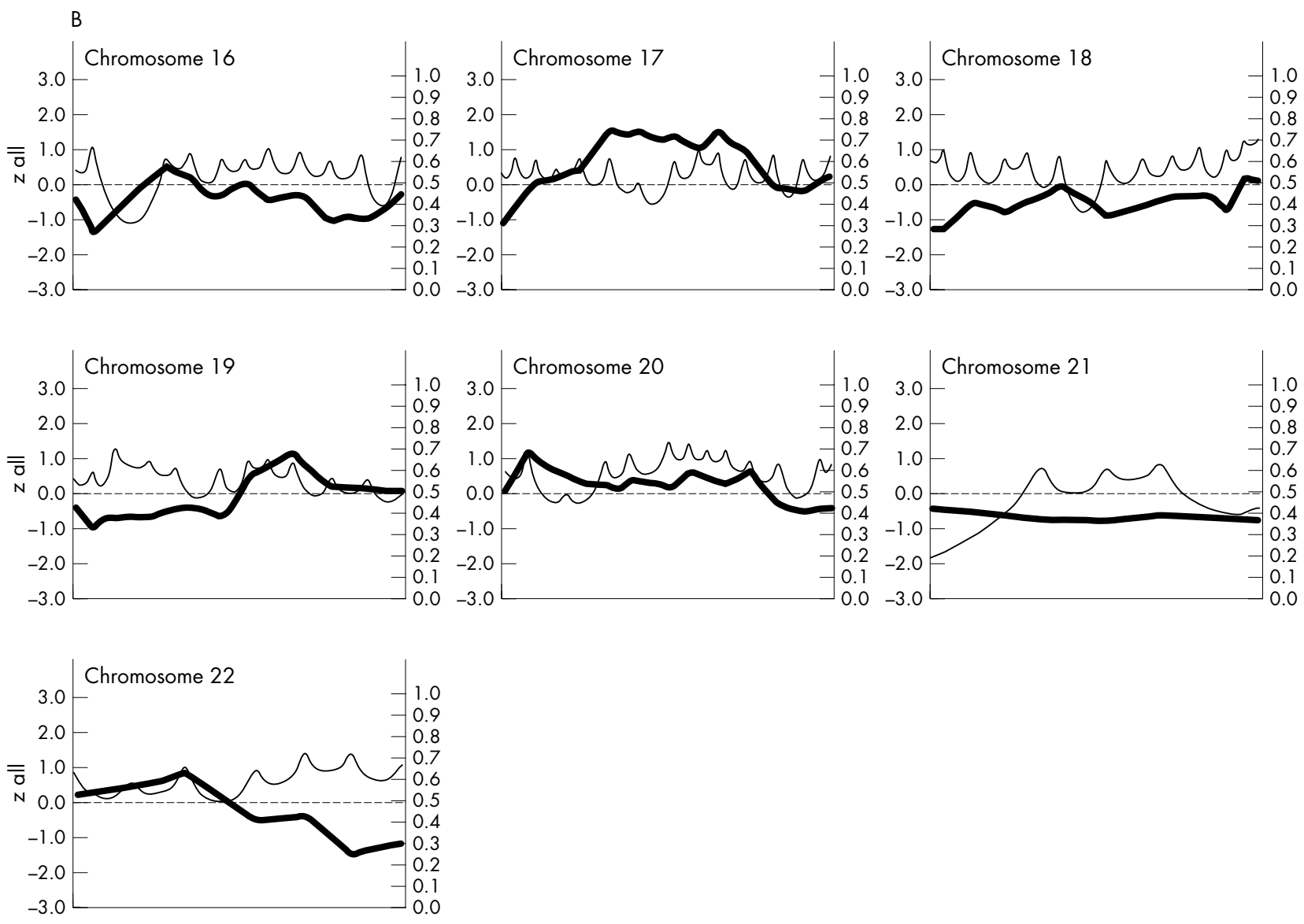

Figure 2B Results of multipoint NPL analysis at stage 1 (pedigrees 1-9, chromosomes 15-22). Thicker curves show NPL scores and thinner curves show information content values. Dotted lines are the zero levels for both NPL and information content values.

Pedmanager and Pedcheck software and haplotyped with Genehunter2 to check for double recombinants. The lack of a reliable model of inheritance made traditional parametric linkage analysis unsuitable. Instead, we chose to use the nonparametric linkage (NPL) score (z), which calculates whether affected individuals share alleles identical-by-descent more often than expected by chance. All autosomal chromosomes were analysed. The X chromosome was not included in the analysis because there is no evidence supporting $\mathrm{X}$ linked inheritance in our families.

The IRF6 gene was screened for mutations using intronic primers flanking all coding exons and the non-coding exons 1 and 2. ${ }^{1}$ For amplifying each exon, 15 ng of genomic DNA was used in the following conditions: $1.5 \mathrm{mM} \mathrm{MgCl} 2,1 \mu \mathrm{M}$ of each primer, $0.2 \mathrm{mM}$ of each dNTP, and $0.04 \mathrm{U} / \mu \mathrm{l}$ of AmpliTaq DNA polymerase (Applied Biosystems) or Hot Star Taq (Qiagen; www.qiageninstruments.com) using the suppliers' buffers and recommendations. Primer sequences are available upon request. PCR products were then cleaned from non-incorporated primers and dNTPs using the GFX PCR DNA purification kit (Amersham Biosciences; www4.amershambiosciences.com), further sequenced using the DYEnamic ET Dye terminator kit (Amersham Biosciences), and cleaned of non-incorporated dideoxynucleotides by ethanol precipitation. Sequencing products were injected for $40-80 \mathrm{~s}$ at $3 \mathrm{~kW}$ and electrophoresed either for $100 \mathrm{~min}$ at $9 \mathrm{~kW}$ or for $180 \mathrm{~min}$ at $6 \mathrm{~kW}$ on a MegaBACE 1000 instrument (Molecular Dynamics). Each exon was sequenced in both directions using the same primers as in the PCR amplification step. Sequences were visualised and analysed using Sequence Analyser v 3.0 software (Amersham Biosciences), as well as the Gap4 Staden package.

\section{RESULTS}

\section{Stage 1}

A genome-wide scan (chromosomes 1-22 with 442 polymorphic markers from the ABI linkage mapping set and with additional markers in chromosomes 1, 2, and 4) of nine multiplex pedigrees detected no significant linkage. The highest NPL score was seen in chromosome $1 \quad \mathrm{z}=2.06$, $\mathrm{p}=0.033$, information content 0.58 ) at a position $50 \mathrm{cM}$ from lpter. NPL scores reaching values over 1.5 were seen in chromosomes $2(z=1.97, p=0.038), 6(z=1.58, p=0.062)$, $11(\mathrm{z}=1.60, \mathrm{p}=0.061), 12(\mathrm{z}=1.80, \mathrm{p}=0.045)$, and 17 $(\mathrm{z}=1.58, \mathrm{p}=0.062)$. The NPL scores and information content values over entire chromosomes are shown in fig $2 \mathrm{~A}$ and $\mathrm{B}$.

\section{Stage 2}

Analysis of candidate region 1p34 and entire chromosomes 2 and 4 in 24 multiplex families: when using data from all 24 pedigrees, the NPL score in chromosome 1 at position $50.3 \mathrm{cM}$ fell to $1.31(\mathrm{p}=0.098)$. The highest NPL score in the VWS linked region in $1 \mathrm{p} 34$ was 1.52 ( $\mathrm{p}=0.069$, inf. cont. 0.86 ) at position $61 \mathrm{cM}$ (fig 3 ). When screening the entire chromosomes 2 and 4 in the 24 multiplex pedigrees, the highest NPL scores were $2.29(\mathrm{p}=0.016$, inf. cont. 0.67) at position $27.10 \mathrm{cM}$ and $1.56(\mathrm{p}=0.064$, inf. cont. 0.67) at position $100 \mathrm{cM}$, respectively (fig 3 ). NPL scores over 1.5 $(\mathrm{p}<0.05)$ were seen in chromosome 2 at $\sim 5-30 \mathrm{cM}$. The initial scan of nine families did not find any linkage in chromosome 4, but additional families and a denser marker map raised a narrow and shallow peak of $1.56(\mathrm{p}=0.064)$ at $100 \mathrm{cM}$. 

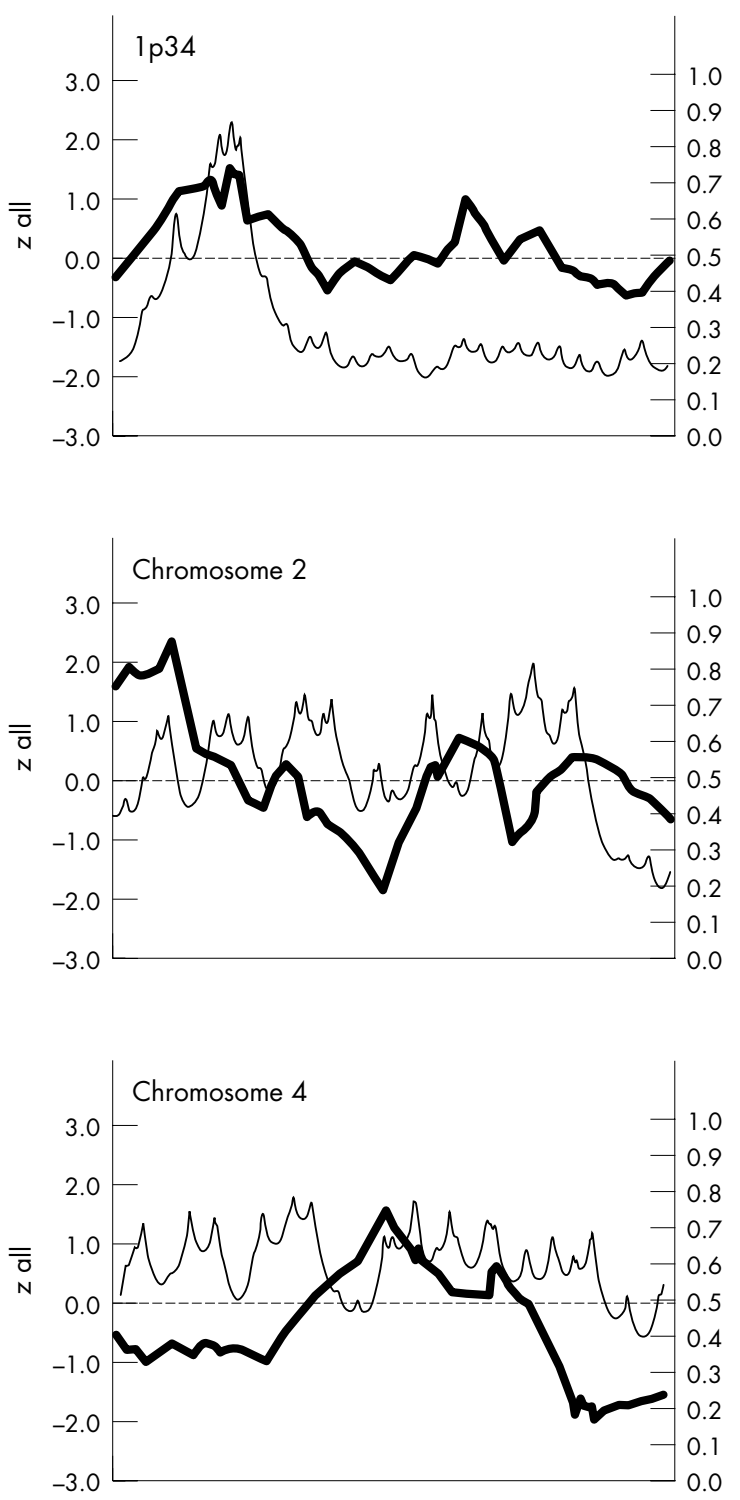

Figure 3 Results of multipoint NPL analysis of chromosomes 1p34, 2, and 4 (in pedigrees 1-24). Thicker curves show NPL scores and thinner curves show information content values. Dotted lines are the zero levels for both NPL and information content values.

\section{Exclusion of IRF6 mutations}

Altogether, 10 affected and nine healthy individuals belonging to nine families were screened for mutations in the IRF6 gene. All coding exons of the gene (that is, exons 3-8 and the translated part of exon 9) and the two non-coding ( $5^{\prime}$ UTR) exons 1 and 2 were screened by direct sequencing. No mutation/polymorphism was detected in the coding region of the IRF6 gene in the individuals tested. However, a common polymorphism $(\mathrm{A} / \mathrm{G})$ located $73 \mathrm{bp}$ before the start codon was detected in exon 2. This polymorphism is referred to as rs861019/ss1266169 in the SNP database (http:// www.ncbi.nlm.nih.gov/SNP/). Allele frequencies were $0.8 /$ 0.2 in the 10 affected individuals and $0.72 / 0.28$ in the nine healthy individuals. This polymorphism does not seem to introduce any new splice site or start codon.

\section{DISCUSSION}

Non-syndromic cleft palate can be considered a genetically complex disease. On the basis of previous studies, it seems probable that both extrinsic and intrinsic factors have an impact on cleft palate formation. No clear Mendelian inheritance pattern can be detected, and locus heterogeneity may be involved. Traditional linkage analysis is not suitable because of the lack of precise parameters.

The results from the genome-wide scan showed no evidence of significant linkage. However, several interesting regions with suggestive linkage were found. In the initial scan with nine pedigrees, the highest NPL score was seen in chromosome $1 \mathrm{p}$ in the same region $(48-52 \mathrm{cM}, \mathrm{p}<0.05)$ as that linked to VWS in a large Finnish pedigree (39-89 cM, $\mathrm{p}<0.0005){ }^{42}$ However, at the second stage, with 15 additional families and six additional markers in 1p34, the NPL scores fell below $1.52(p=0.069)$. When they performed genome-wide scans in $\mathrm{CL} / \mathrm{P}$, Prescott et $a l^{34}$ and Marazita et $a l^{35}$ found positive regions in chromosome 1 at $15-25 \mathrm{cM}$ (lp36) and $100 \mathrm{cM}$, respectively. ${ }^{35}$ Significant NPL scores were also found in 1 p36 in Italian families with nonsyndromic orofacial clefts. ${ }^{43}$ The suggestive NPL scores in our study seemed to be slightly more centromeric compared to the positive scores obtained by Martinelli ${ }^{43}$ and Prescott et al. ${ }^{34}$ We consider both chromosomal regions 1 p34 and 1p36 to be candidate regions in orofacial clefting. We also wanted to rule out the role of the IRF6 gene in our families; no mutations were detected.

When screening all 24 families, suggestive NPL scores $(>1.5, \mathrm{p}<0.05)$ were seen in chromosome 2 at $\sim 5-30 \mathrm{cM}$ (2p24-p25), with a maximum value of $2.29(\mathrm{p}=0.016)$. This is the first time that $2 \mathrm{p} 24-\mathrm{p} 25$ has been reported to show any suggestive linkage to $\mathrm{CPO}$. Candidate gene transforming growth factor alpha (TGF $\alpha)$ is located in $2 \mathrm{pl} 3$ ( $\sim 7 \mathrm{l} \mathrm{cM})$, outside our positive region. The previously reported CPO candidate region, 2q32, did not show any evidence of linkage in our study. ${ }^{32}$ In chromosome 4 , the only positive peak (NPL 1.56, $\mathrm{p}=0.064$ ) was at $100 \mathrm{cM}$. Thus, our study could not confirm the role of previously reported candidate regions in chromosome 4 in orofacial clefting. ${ }^{27} 445$

In chromosome 6, NPL scores over $1.5(p=0.062-0.07)$ were seen at 137-142 cM (6q22). The orofacial cleft (OFCl, MIM 119530) region in 6p24 did not show any evidence of linkage in our families. ${ }^{46-49}$ No linkage or association of orofacial clefts to $6 \mathrm{q} 22$ has previously been reported. In chromosome 12 we found a suggestive linkage at $111.0 \mathrm{cM}$ (12q21) $(\mathrm{z}=1.80, \mathrm{p}<0.05)$. Marazita et al found significant associations for two loci in chromosome 12 but at different locations (78 and $166 \mathrm{cM}) .^{35}$ In chromosome 17, the highest NPL $(\mathrm{z}=1.54, \mathrm{p}=0.067)$ score was at $90 \mathrm{cM}$ and is distal to the candidate gene RARA located in chromosome 17q21.

Although none of the regions reached the level required for significant susceptibility loci, we consider regions 1p34, $2 \mathrm{p} 24-\mathrm{p} 25$, and $12 \mathrm{q} 21$ to be candidate regions for further studies on orofacial clefting, especially cleft palate.

\section{ACKNOWLEDGEMENTS}

We thank all members of the affected families for their participation. We thank Mrs Riitta Lehtinen and Mrs Sinikka Lindh for technical aid.

\section{ELECTRONIC-DATABASE INFORMATION}

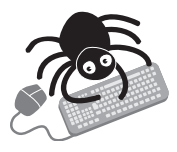

The URLs referred to in this study are: Amersham Biosciences, www4.amershambiosciences.com; Applied Biosystems, www.appliedbiosystems.com; Finnish Genome Center, http://www.genome. helsinki.fi; Marshfield Comprehensive Human Genetic Map, http://research.marshfieldclinic.org/genetics/ Map Markers/maps/indexmap.html; Online Mendelian Inheritance in Man (OMIM), http:// www.ncbi.nlm.nih.gov/Omim/; Qiagen, www. qiageninstruments.com; The Transgenic/Targeted Mutation Database, http://tbase.jax.org/; and SNP database, http://www.ncbi.nlm.nih.gov/SNP/. 


\section{Authors' affiliations}

H Koillinen, Department of Medical Genetics, University of Helsinki, Helsinki, Finland

P Lahermo, Finnish Genome Center, University of Helsinki, Helsinki, Finland

J Rautio, J Hukki, Cleft Center, University Hospital of Helsinki, Helsinki, Finland

M Peyrard-Janvid, J Kere, Department of Biosciences at Novum, Karolinska Institute, Stockholm, Sweden

This study was supported by the Sigrid Juselius Foundation, the Academy of Finland, and the Helsinki University Hospital Research Funds.

Conflict of interest: none declared.

Correspondence to: Hannele Koillinen, Department of Medical Genetics, Kiinamyllynkatu 10, 20520 Turku, Finland; hannele.koillinen@ utu.fi

Revised version received 17 May 2004

Accepted for publication 18 June 2004

\section{REFERENCES}

1 Kondo S, Schutte BC, Richardson RJ, Bjork BC, Knight AS, Watanabe Y, Howard E, Ferreira de Lima RLL, Daack-Hirsch S, Sander A, McDonaldMcGinn DM, Zackai EH, Lammer EJ, Aylsworth AS, Ardinger HH, Lidral AC, Pober BR, Moreno L, Arcos-Burgos M, Valencia C, Houdayer C, Bahuau M, Moretti-Ferreira D, Richieri-Costa A, Dixon MJ, Murray JC. Mutations in IRF6 cause Van der Woude and popliteal pterygium syndromes. Nat Genet 2002:32:285-9.

2 Satokata I, Maas R. Msx 1 deficient mice exhibit cleft palate and abnormalities of craniofacial and tooth development. Nat Genet 1994;6:348-56.

3 Murray JC. Gene/environment causes of cleft lip and/or palate. Clin Genet 2002;61:248-56.

4 Romitti PA, Lidral AC, Munger RG, Daack-Hirsch S, Burns TL, Murray JC. Candidate genes for nonsyndromic cleft lip and palate and maternal cigarette smoking and alcohol consumption: evaluation of genotype-environment interactions from a population-based case-control study of orofacial clefts. Teratology 1999:59:39-50.

5 Hwang SJ, Beaty TH, Panny SR, Street NA, Joseph JM, Gordon S, Mclntosh I, Francomano CA. Association study of transforming growth factor alpha (TGF alpha) Taql polymorphism and oral clefts: indication of gene-environment interaction in a population-based sample of infants with birth defects. Am J Epidemiol 1995; 141:629-36.

6 Shaw GM, Wasserman CR, Lammer EJ, O'Malley CD, Murray JC, Basart AM, Tolarova MM. Orofacial clefts, parental cigarette smoking, and transforming growth factor-alpha gene variants. Am J Hum Genet 1996;58:551-61.

7 Shaw GM, Wasserman CR, Murray JC, Lammer EJ. Infant TGF-alpha genotype, orofacial clefts, and maternal periconceptional multivitamin use. Cleft Palate Craniofac J 1998;35:366-70.

8 Khoury MJ, Gomez-Farias L, Mulinare J. Does maternal cigarette smoking during pregnancy cause cleft lip and palate in offspring? Am J Dis Child 1989:143:333-7.

9 Lorente C, Cordier S, Goujard J, Ayme S, Bianchi F, Calzolari E, De Walle HE, Knill-Jones R. Tobacco and alcohol use during pregnancy and risk of oral clefts. Occupational Exposure and Congenital Malformation Working Group. Am J Public Health 2000;90:415-9.

10 Saxen I. Etiological variables in oral clefts. PhD thesis. University of Helsinki, 1975.

11 Shaw GM, Lammer EJ, Wasserman CR, O'Malley CD, Tolarova MM. Risks of orofacial clefts in children born to women using multivitamins containing folic acid periconceptionally. Lancet 1995;346:393-6.

12 Czeizel AE, Timar L, Sarkozi A. Dose-dependent effect of folic acid on the prevention of orofacial clefts. Pediatrics 1999;104:66

13 Christensen K, Mitchell LE. Familial recurrence-pattern analysis of nonsyndromic isolated cleft palate-a Danish registry study. Am J Hum Genet 1996:58:182-90.

14 Nordström R, Laatikainen T, Juvonen T, Ranta R. Cleft-twin sets in Finland 1948-1987. Cleft Palate Craniofac J 1996;33:340-7.

15 Fogh-Andersen P. Inheritance of harelip and cleft palate. Copenhagen: Busck 1942.

16 Demanais F, Bonati-Pellie C, Briard ML, Feingold J. An epidemiological and genetic study of facial clefting in France. Segregation analysis. J Med Genet 1984;21:436-40

17 FitzPatrick D, Farrall M. An estimation of the number of susceptibility loci for isolated cleft palate. J Craniofac Genet Dev Biol 1993;13:230-5.

18 Curtis EJ, Fraser F, Warburton D. Congenital cleft lip and palate. Am J Dis Child 1961;102:853-7.

19 Murray JC. Invited editorial: face facts: genes, environment and clefts. Am J Hum Genet 1995;57:227-32.

20 Wyszynski DF, Beaty TH, Maestri NE. Genetics of nonsyndromics oral clefts revisited. Cleft Palate Craniofac J 1996;33:406-17.

21 Schutte BC, Murray JC. The many faces and factors of orofacial clefts. Hum Mol Genet 1999;8:1853-9.

22 Lilius P. Epidemiology of cleft lip and palate in Finland 1975-1985. PhD thesis. University of Helsinki, 1992.
23 Vanderas A. Incidence of cleft lip, cleft palate, and cleft lip and palate among races: a review. Cleft Palate J 1987;24:216-25.

24 Shiang R, Lidral AC, Ardinger HH, Buetow KH, Romitti PA, Munger RG, Murray JC. Association of transforming growth-factor alpha gene polymorphisms with non-syndromic cleft palate only (CPO). Am J Hum Genet 1993:53:836-43.

25 Lidral AC, Romitti PA, Basart AM, Doetschman T, Leysens NJ, Daack-Hirsch S, Semina EV, Johnson LR, Machida J, Burds A, Parnell TJ, Rubenstein JL, Murray JC. Association of MSX1 and TGFB3 with nonsyndromic clefting in humans. Am J Hum Genet 1998;63:557-68.

26 Mitchell LE, Murray JC, O'Brien S, Christensen K. Evaluation of two putative susceptibility loci for oral clefts in the Danish population. Am J Epidemiol 2001; 15:1007-15.

27 Hecht JT, Mulliken JB, Blanton SH. Evidence for a cleft palate only locus on chromosome 4 near MSX1. Am J Med Genet 2002;15:406-7.

28 van den Boogaard MJ, Dorland M, Beemer FA, van Amstel HK. MSXI mutation is associated with orofacial clefting and tooth agenesis in humans. Nat Genet 2000;24:342-3.

29 Hecht JT, Wang Y, Blanton SH, Daiger SP. Van der Woude syndrome and nonsyndromic cleft lip and palate. Am J Hum Genet 1992;52:442-4.

30 Brewer C, Holloway S, Zawalnyski P, Schinzel A, FitzPatrick D. A chromosomal deletion map of human malformations. Am J Hum Genet 1998;63:1153-9.

31 Brewer C, Holloway S, Zawalnyski P, Schinzel A, FitzPatrick D. A chromosomal duplication map of malformations: regions of suspected haploand triplolethality-and tolerance of segemental aneuploidy-in humans. Am J Hum Genet 1999;64:1702-8.

32 Brewer CM, Leek JP, Green AJ, Holloway S, Bonthron DT, Markham AF, FitzPatrick DR. A locus for isolated cleft palate, located on human chromosome 2q32. Am J Hum Genet 1999:65:387-96.

33 Prescott N, Lees JM, Malcolm S, Winter R. Non-syndromic cleft lip and palate: a genome-wide sib-pair analysis. Am J Hum Genet Suppl 1998;63:A1764.

34 Prescott NJ, Lees MM, Winter RM, Malcolm S. Identification of susceptibility loci for non-syndromic cleft lip with or without cleft palate in a two stage genome scan of affected sib pairs. Hum Genet 2000;106:345-50.

35 Marazita ML, Field LL, Cooper ME, Tobias R, Maher BS, Peanchitlertkajorn S, Liu Y. Genome scan for loci involved in cleft lip with or without cleft palate, in Chinese multiplex families. Am J Hum Genet 2002;71:349-64.

36 Neiswenger K, Ford MD, Cooper ME, Goldstein TH, Petiprin SS, Bardi KM, Brandon CA, Giles RF, Marazita ML. Genome scan of cleft lip with and without cleft palate (CL/P): Part II: Broadening the phenotype to include velopharyngeal incompetence (VPi). Am J Hum Genet 2003;73(suppl):493.

37 Zeiger JS, Hetmanski JB, Beaty TH, VanderKolk CA, Wyszynski DF, BayleyWilson JE, Ortiz de Luna R, Perandones C, Tolarova MM, Mosby T, Bennun R, Segovia R, Calda P, Pugh EW, Doheny K, Mclntosh I. Evidence of linkage of nonsyndromic cleft lip with or without cleft palate to a region in chromosome 2. Eur J Hum Genet 2003;11:835-9.

38 Wyszynski DF, Albacha-Hejazi $H$, Aldirani M, Hammod M, Shkair $H$, Karam A, Alashkar J, Holmes TN, Pugh EW, Doheny KF, Mclntosh I, Beaty TH, Bayley-Wilson JE. A genome-wide scan for loci predisposing to nonsyndromic cleft lip with or without cleft palate in two large Syrian families. Am J Med Genet 2003;123A: 140-7.

39 Koillinen H, Ollikainen $\bigvee$, Rautio J, Hukki J, Kere J. Linkage and linkage disequilibrium searched between non-syndromic cleft palate and fou candidate loci. J Med Genet 2003:40:464-8.

40 Lahiri DK, Nurnberger Jl. A rapid non-enzymatic method for the preparation of HMW DNA from blood for RFLP studies. Nucleic Acids Res 1991; 19:5444.

41 Kruglyak L, Daly MJ, Reeve-Daly MP, Lander ES. Parametric and nonparametric linkage analysis: a unified multipoint approach. Am J Hum Genet 1996;58:1347-63.

42 Koillinen H, Wong FK, Rautio J, Ollikainen V, Karsten A, Larson O, Teh BT, Huggare J, Lahermo P, Larsson C, Kere J. Mapping of the second locus for the Van der Woude syndrome to chromosome 1p34. Eur J Hum Genet $2001 ; 9: 747-52$

43 Martinelli M, Scapoli L, Pezzetti F, Carinci F, Francioso F, Baciliero U, Padula $E$, Carinci P, Tognon M. Linkage analysis of three candidate regions of chromosome 1 in non-syndromic familial orofacial cleft. Ann Hum Genet 2001;65:465-71.

44 Beiraghi S, Foroud T, Diouhy S, Bixler D, Conneally PM, Delozier-Blanchet D, Hodes ME. Possible localization of a major gene for cleft lip and palate to $4 \mathrm{q}$. Clin Genet 1994;46:255-6.

45 Mitchell LE, Healey SC, Chenevix-Trench G. Evidence for an association between non-syndromic cleft lip with or without cleft palate and a gene located on the long arm of chromosome 4. Am J Hum Genet 1995;57:1130-6.

46 Davies AF, Stephens RJ, Olavesen MG, Heather L, Dixon MJ, Magee A, Flinter $F$, Ragoussis J. Evidence of a locus for orofacial clefting on human chromosome 6p24 and STS content map of the region. Hum Mol Genet 1995; $4: 121-8$.

47 Pezzetti F, Scapoli L, Martinelli M, Carinci F, Bodo M, Carinci P, Tognon M. A locus in 2p13-p14 (OFC2), in addition to that mapped in 6p23, is involved in non-syndromic familial orofacial cleft malformation. Genomics 1998; 15:299-305

48 Scapoli L, Pezzetti F, Carinci F, Martinelli M, Carinci P, Tognon M. Evidence of linkage to 6p23 and genetic heterogeneity in nonsyndromic cleft lip with or without cleft palate. Genomics 1997;43:216-20.

49 Scapoli C, Collins A, Martinelli M, Pezzetti F, Scapoli L, Tognon M. Combined segregation and linkage analysis of nonsyndromic orofacial cleft in two candidate regions. Ann Hum Genet 1999;63:17-25. 